\title{
The Equity Risk Premium amid a Global Financial Crisis
}

\author{
John R. Graham \\ Fuqua School of Business, Duke University, Durbam, NC 27708, USA \\ National Burean of Economic Research, Cambridge, MA 02912, USA \\ Campbell R. Harvey* \\ Fuqua School of Business, Duke University, Durbam, NC 27708, USA \\ National Bureau of Economic Research, Cambridge, MA 02912, USA
}

\begin{abstract}
We analyze the history of the equity risk premium from surveys of U.S. Chief Financial Officers (CFOs) conducted every quarter from June 2000 to March 2009. The risk premium is the expected 10-year S\&P 500 return relative to a 10year U.S. Treasury bond yield. The last two surveys were conducted during the darkest parts of a global financial crisis and our results show that the equity premium sharply increased during the crisis. The survey also provides measures of cross-sectional disagreement about the risk premium, skewness, and a measure of individual uncertainty. The level of disagreement in late 2008 and early 2009 is 64\% higher than 2007 levels. We also present evidence on the determinants of the long-run risk premium. Our analysis suggests the level of the risk premium closely tracks both market volatility (reflected in the VIX index) as well as credit spreads.
\end{abstract}

JEL Classification: G11, G31, G12, G14

Keywords: Cost of capital, financial crisis, equity premium, long-term market returns, long-term equity returns, expected excess returns, disagreement, individual uncertainty, skewness, asymmetry, survey methods, risk and reward, TIPs, VIX, Credit spreads

*Corresponding author, Telephone: +1 919.660.7768, Fax: +1 919.660.8030, E-mail: cam.harvey@duke.edu. We appreciate the research assistance of Hai Huang, Runeet Kishore., Nikhil Sharma, and Stephen Saroki. Version May 14, 2009 


\section{Introduction}

We analyze the results of the most recent survey of Chief Financial Officers (CFOs) conducted by Duke University and CFO Magazine. The survey closed on February 26, 2009 and measures expectations beginning in the second quarter of 2009. In particular, we poll CFOs about their longterm expected return on the S\&P 500. Given the current 10-year T-bond yield, we provide estimates of the equity risk premium and show how the premium changes through time. We also provide information on the disagreement over the risk premium as well as average confidence intervals.

\section{Method}

\subsection{Design}

The quarterly survey of CFOs was initiated in the third quarter of $1996 .{ }^{1}$ Every quarter, Duke University polls financial officers with a short survey on important topical issues (Graham and Harvey, 2009). The usual response rate for the quarterly survey is 5\%-8\%. Starting in June of 2000, a question on expected stock market returns was added to the survey. Fig. 1 summarizes the results from the risk premium question. While the survey asks for both the one-year and ten-year expected returns, we focus on the ten-year expected returns herein, as a proxy for the market risk premium.

The executives have the job title of CFO, Chief Accounting Officer, Treasurer, Assistant Treasurer, Controller, Assistant Controller, or Vice President (VP), Senior VP or Executive VP of Finance. Given that the overwhelming majority of survey respondents hold the CFO title, for simplicity we refer to the entire group as CFOs.

\subsection{Delivery and response}

In the early years of the survey, the surveys were faxed to executives. The delivery mechanism was changed to the Internet starting with the December 4, 2001 survey. Among other things, we now collect the respondents' IP addresses (though not their identity or company) and are able examine consistency of responses across different surveys. Respondents are given four business days

\footnotetext{
1 The surveys from 1996Q3-2004Q2 were partnered with a well-known national organization of financial executives. The 2004Q3 and 2004Q4 surveys were solely Duke University surveys, which used Duke mailing lists (previous survey respondents who volunteered their email addresses) and purchased email lists. The surveys from 2005Q1 to present are partnered with CFO. The sample includes both the Duke mailing lists and the CFO subscribers that meet the criteria for policy-making positions.
} 
to fill out the survey, then a reminder is sent allowing another four days. Usually, two-thirds of the surveys are returned within two business days.

The response rate of 5-8\% could potentially lead to a non-response bias. There are five reasons why we are not overly concerned with the response rate. First, our response rate is within the range that is documented in many other survey studies. Second, Graham and Harvey (2001) conduct a standard test for non-response biases (which involves comparing the results of those that fill out the survey early to the ones that fill it out late) and find no evidence of bias. Third, Brav, Graham, Harvey and Michaely (2005) conduct a captured sample survey at a national conference in addition to an Internet survey. The captured survey responses (to which over two-thirds participated) are qualitatively identical to those for the Internet survey (to which $8 \%$ responded), indicating that nonresponse bias does not significantly affect their results. Fourth, Brav et al. contrast survey responses to archival data from Compustat and find archival evidence for the universe of Compustat firms that is consistent with the responses from the survey sample. Fifth, Campello, Graham, and Harvey (2009a) show that the December 2008 response sample is fairly representative of the firms included in the commonly used Compustat database.

\subsection{Data integrity}

In each quarter, we trim the top two and bottom two risk premium observations. Given that we have, on average, about 300 responses each quarter, this implies a less than $1 \%$ trim in each of the tails. In addition, of the over 11,000 survey observations, there was only a single observation (in the June 2000 survey) that we consider not credible. The trimmed and untrimmed data are very similar with the exception of the June 2000 survey.

There are two other steps that we take. First, for the purpose of some of our statistics, we require that the expected risk premium forecast be no more than the best-case scenario and no less than the worst-case scenario. If the ordering is violated, then the observation is deleted. Second, there are a few instances in which respondents report in decimals rather than percentages. In these cases, we change the inputs to adhere to the survey format rather than deleting the observations. 


\subsection{The 2009 results}

The expected market return questions are a subset of a larger set of questions in the quarterly survey of CFOs. The survey usually contains between eight and ten questions. Some of the questions are repeated every quarter and some change through time depending on economic conditions. The historical surveys can be accessed at http://www.cfosurvey.org. Appendix 1 shows the risk premium question in the most recent survey.

While the survey is anonymous, we collect demographic information on seven firm characteristics, including industry, sales revenue, number of employees, headquarters location, ownership (public or private), and proportion of foreign sales.

During the past nine years, we have collected 11,288 responses to the survey. Panel A of Table 1 presents the date that the survey window opened, the number of responses for each survey, the 10year Treasury bond rate, as well as the average and median expected excess returns. There is relatively little time variation in the risk premium. This is confirmed in Fig. 1, which displays the historical risk premiums contained in Table 1. The current premium, 4.74\%, is the highest reading in the history of the survey. The March 2009 survey shows that the expected annual S\&P 500 return is $7.49 \%$ and the implied risk premium is $4.74 \%(7.49-2.75) .{ }^{2}$ The expected annual S\&P 500 return is roughly the same level as a year ago. A major factor in the increase in the premium is the 10-year bond yield falling by over 100 basis points.

Panel B of Table 1 presents some summary statistics that pool all 11,288 responses. The overall average ten-year risk premium return is $3.46 \% .^{3}$ The standard deviation is $2.67 \%$.

The cross-sectional standard deviation across the individual CFO forecasts in a quarter is a measure of the disagreement of the participants in each survey. Disagreement has sharply increased during the global financial crisis. The average disagreement in 2007 averaged 2.5\%. The most recent

\footnotetext{
2 See, for example, Ghysels (1998), Welch (2000, 2001, 2009), Ghysels (1998), Fraser (2001), Harris and Marston (2001), Pástor and Stambaugh (2001), Fama and French (2002), Goyal and Welch (2003), Graham and Harvey (2003), Ang and Bekaert (2005), Fernandez (2004, 2006, 2009) for studies of the risk premium.

${ }^{3}$ Using the Ibbotson Associates data from January 1926 through March 2009, the arithmetic (geometric) average return on the S\&P 500 over and above the 30-day U.S. Treasury bill is 7.20\% (5.40\%). Using data from April 1953-March 2009, the arithmetic (geometric) risk premium is 5.64\% (4.56\%). Over the April 1953-March 2009 period, the arithmetic average return on the S\&P 500 over the 10-year U.S. Treasury bond is 4.21\%. Fama and French (2002) study the risk premium on the S\&P 500 from 1872-2000 using fundamental data. They argue that the ex ante risk premia is between $2.55 \%$ and $4.32 \%$ for 1951-2000 period. Ibbotson and Chen (2001) estimate a long-term risk premium between 4 and 6\%. Also see Siegel (1999), Asness (2000), Heaton and Lucas (2000) and Jagannathan, McGratten and Scherbina (2001).
} 
observation is $4.11 \%$-- a two-thirds increase and the highest observation on record.

We also report information on the average of the CFOs' assessments of the one in ten chance that the market will exceed or fall below a certain level. In the most recent survey, the worst case total return is $1.27 \%$ which is a record low. The best-case return is $12.40 \%$ which is a record high. This reinforces the recent increase in the degree of uncertainty.

With information on the $10 \%$ tails, we construct a probability distribution for each respondent. We use Davidson and Cooper's (1976) method to recover each respondent's probability distribution:

$$
\text { Variance }=([x(0.90)-x(0.10)] / 2.65)^{2}
$$

where $x(0.90)$ and $x(0.10)$ represent the $90^{\text {th }}$ and $10^{\text {th }}$ percentiles of the respondent's distribution. Keefer and Bodily (1983) show that this simple approximation is the preferred method of estimating the variance of a probability distribution of random variables, given information about the $10^{\text {th }}$ and $90^{\text {th }}$ percentiles. The average of individual volatilities has also sharply increased. The average in 2007 was $3.21 \%$ and the current reading is $4.23 \%$-- another new high.

There is also a natural measure of asymmetry in each respondent's response. We look at the difference between each individual's 90\% tail and the mean forecast and the mean minus the 10\% tail. Hence, if the respondent's forecast of the excess return is $6 \%$ and the tails are $-8 \%$ and $+11 \%$, then the distribution is negatively skewed with a value of $-9 \%(=5 \%-14 \%)$. As with the usual measure of skewness, we cube this quantity and standardize by dividing by the cube of the individual standard deviation. In every quarter's survey, there is on average negative skewness in the individual forecasts. The average asymmetry became more negative at -0.47 and is currently at a record low level. 
Table

Summary statistics based on the responses from the

36 CFO Outlook Surveys from June 2000 to February 2009

A. By quarter

\begin{tabular}{|c|c|c|c|c|c|c|c|c|c|c|c|}
\hline Survey date & $\begin{array}{c}\text { Survey } \\
\text { for }\end{array}$ & $\begin{array}{c}\text { Number of } \\
\text { survey } \\
\text { responses }\end{array}$ & $\begin{array}{c}10 \text {-year } \\
\text { bond } \\
\text { yield }\end{array}$ & $\begin{array}{c}\text { Average } \\
\text { risk } \\
\text { premium }\end{array}$ & $\begin{array}{c}\text { Median } \\
\text { risk } \\
\text { premium }\end{array}$ & $\begin{array}{l}\text { Disagreement } \\
\text { (standard } \\
\text { deviation of } \\
\text { risk premium } \\
\text { estimates) }\end{array}$ & $\begin{array}{c}\text { Average of } \\
\text { individual } \\
\text { standard } \\
\text { deviations }\end{array}$ & $\begin{array}{l}\text { individuals' } \\
\text { worst } 10 \% \\
\text { market } \\
\text { return } \\
\text { scenario } \\
\end{array}$ & $\begin{array}{l}\text { Average of } \\
\text { individuals' } \\
\text { best } 10 \% \\
\text { market return } \\
\text { scenario }\end{array}$ & $\begin{array}{c}\text { Skewness of } \\
\text { risk } \\
\text { premium } \\
\text { estimates }\end{array}$ & $\begin{array}{c}\text { Average of } \\
\text { individuals' } \\
\text { asymmetry }\end{array}$ \\
\hline 6-Jun-00 & 2000Q3 & 206 & 6.10 & 4.35 & 3.9 & 2.99 & & & & 0.81 & \\
\hline 7-Sep-00 & 2000Q4 & 184 & 5.70 & 4.65 & 4.3 & 2.70 & & & & 0.49 & \\
\hline 4-Dec-00 & 2001Q1 & 239 & 5.50 & 4.20 & 4.5 & 2.31 & & & & 0.37 & \\
\hline 12-Mar-01 & 2001Q2 & 137 & 4.90 & 4.46 & 4.1 & 2.59 & & & & 0.38 & \\
\hline 7-Jun-01 & 2001Q3 & 204 & 5.40 & 3.79 & 3.6 & 2.43 & & & & 0.49 & \\
\hline 10-Sep-01 & 2001Q4 & 198 & 4.80 & 3.77 & 3.2 & 2.53 & & & & -0.11 & \\
\hline 4-Dec-01 & 2002Q1 & 275 & 4.70 & 3.98 & 3.3 & 2.34 & & & & 0.66 & \\
\hline 11-Mar-02 & 2002Q2 & 234 & 5.30 & 2.88 & 2.7 & 2.17 & 3.21 & 3.66 & 12.23 & 0.30 & -0.28 \\
\hline 4-Jun-02 & 2002Q3 & 321 & 5.00 & 3.18 & 3.0 & 2.59 & 3.41 & 3.11 & 12.15 & 1.96 & -0.39 \\
\hline 16-Sep-02 & 2002Q4 & 363 & 3.90 & 4.00 & 4.1 & 2.27 & 3.36 & 3.10 & 12.01 & 1.03 & -0.25 \\
\hline 2-Dec-20 & 2003Q1 & 283 & 4.20 & 3.71 & 3.8 & 2.39 & 3.19 & 3.38 & 11.83 & 1.31 & -0.28 \\
\hline 19-Mar-03 & 2003Q2 & 180 & 3.70 & 3.66 & 3.3 & 2.12 & 3.57 & 1.92 & 11.40 & 0.49 & -0.60 \\
\hline 16-Jun-03 & 2003Q3 & 368 & 3.60 & 3.89 & 4.4 & 2.34 & 3.74 & 2.17 & 12.07 & 0.89 & -0.33 \\
\hline 18-Sep-03 & 2003Q4 & 165 & 4.30 & 3.21 & 3.7 & 1.87 & 2.80 & 3.34 & 10.78 & -0.02 & -0.42 \\
\hline $10-D e c-03$ & 2004Q1 & 217 & 4.36 & 3.83 & 3.6 & 2.22 & 3.24 & 3.35 & 11.94 & 0.74 & -0.46 \\
\hline 24-Mar-04 & 2004Q2 & 202 & 3.70 & 4.10 & 4.3 & 2.06 & 3.46 & 2.84 & 12.00 & -0.03 & -0.28 \\
\hline 16-Jun-04 & 2004Q3 & 177 & 4.75 & 3.04 & 3.3 & 2.28 & 3.06 & 3.11 & 11.20 & 0.96 & -0.39 \\
\hline 12-Sep-04 & 2004Q4 & 177 & 4.25 & 3.24 & 3.3 & 2.32 & 3.13 & 2.70 & 10.98 & 0.64 & -0.47 \\
\hline 5-Dec-04 & 2005Q1 & 291 & 4.35 & 3.20 & 3.2 & 2.63 & 3.00 & 3.16 & 11.10 & 2.01 & -0.36 \\
\hline 28-Feb-05 & 2005Q2 & 275 & 4.28 & 3.19 & 3.2 & 2.47 & 2.99 & 3.23 & 11.16 & 1.49 & -0.32 \\
\hline 31-May-05 & 2005Q3 & 318 & 4.07 & 2.98 & 2.9 & 2.21 & 3.17 & 2.50 & 10.88 & 0.50 & -0.25 \\
\hline 29-Aug-05 & 2005Q4 & 325 & 4.20 & 2.93 & 2.8 & 2.20 & 3.23 & 2.26 & 10.82 & 0.96 & -0.50 \\
\hline 21-Nov-05 & 2006Q1 & 342 & 4.52 & 2.39 & 2.5 & 2.14 & 3.40 & 2.35 & 11.38 & 0.57 & -0.23 \\
\hline 6-Mar-06 & 2006Q2 & 278 & 4.61 & 2.57 & 2.4 & 2.37 & 3.43 & 2.11 & 11.18 & 1.11 & -0.36 \\
\hline 1-Jun-06 & 2006Q3 & 500 & 5.05 & 2.69 & 3.0 & 2.69 & 3.26 & 3.10 & 11.70 & 2.00 & -0.23 \\
\hline 11-Sep-06 & 2006Q4 & 465 & 4.79 & 2.50 & 2.2 & 2.47 & 3.29 & 2.57 & 11.28 & 1.37 & -0.32 \\
\hline 21-Nov-06 & 2007Q1 & 392 & 4.58 & 3.21 & 3.4 & 2.92 & 3.31 & 2.98 & 11.75 & 1.93 & -0.29 \\
\hline 1-Mar-07 & 2007Q2 & 388 & 4.55 & 3.13 & 3.5 & 2.39 & 3.31 & 2.79 & 11.56 & 1.83 & -0.38 \\
\hline 1-Jun-07 & 2007Q3 & 419 & 4.90 & 2.94 & 3.1 & 2.12 & 3.20 & 3.10 & 11.58 & 0.61 & -0.38 \\
\hline 7-Sep-07 & 2007Q4 & 486 & 4.48 & 3.35 & 3.5 & 2.81 & 3.08 & 3.39 & 11.54 & 1.80 & -0.33 \\
\hline 1-Dec-07 & 2008Q1 & 465 & 4.04 & 3.78 & 4.0 & 2.73 & 3.25 & 2.99 & 11.60 & 1.47 & -0.32 \\
\hline 7-Mar-08 & 2008Q2 & 388 & 3.61 & 3.97 & 4.4 & 2.97 & 3.16 & 3.11 & 11.50 & 2.28 & -0.29 \\
\hline 13-Jun-08 & 2008Q3 & 390 & 4.15 & 3.12 & 2.9 & 2.72 & 3.28 & 2.49 & 11.20 & 2.02 & -0.41 \\
\hline 5-Sep-08 & 2008Q4 & 439 & 3.69 & 3.53 & 3.3 & 2.59 & 3.22 & 2.37 & 10.90 & 1.05 & -0.41 \\
\hline 28-Nov-08 & 2009Q1 & 545 & 3.10 & 4.12 & 3.9 & 3.10 & 3.66 & 1.77 & 11.47 & 1.66 & -0.36 \\
\hline 26-Feb-09 & 2009Q2 & 452 & 2.75 & 4.74 & 4.3 & 4.11 & 4.23 & 1.27 & 12.40 & 1.82 & -0.47 \\
\hline Average of quarters & & 11,288 & 4.44 & 3.51 & 3.46 & 2.51 & 3.30 & 2.77 & 11.50 & 1.05 & -0.36 \\
\hline Standard deviation & & & 0.70 & 0.61 & 0.61 & 0.40 & 0.27 & 0.56 & 0.45 & 0.67 & 0.09 \\
\hline
\end{tabular}

B. By individual responses

Survey for

All dates

11,288

$3.46 \quad 3.30$

2.67

3.48

2.49

11.48

1.49

$-0.34$

\subsection{Recessions, the financial crisis and risk premia}

Our survey now spans two recessions: March 2001-September 2001 as well as the recession that begins in December 2007. Financial theory would suggest that risk premia should vary with the business cycle. Premiums should be highest during recessions and lowest during recoveries. Previous research has used a variety of methods including looking at ex post realized returns to investigate whether there is business-cycle like variation in risk premia. 
While we only have 36 observations and this limits our statistical analysis, we do see important differences. The average risk premium over the entire sample is $3.46 \%$. During recessions, the risk premium is $3.97 \%$ and during non-recessions, the premium falls to $3.37 \%$. We also see variation in disagreement. During recessions, the disagreement among participants is $2.84 \%$ and during nonrecessions only $2.40 \%$.

The recession that began in December 2007 is a much worse than normal recession. For example, the recession of 2001 was relatively mild and lasted only three quarters. The current recession is already double the length and includes some of the highest unemployment since WWII. Nevertheless, the risk premium is not really much different during this recession (so far) than during the 2001 recession. Over the past six quarters, the risk premium has averaged $3.88 \%$.

\subsection{Interviews}

To further explore the risk premium, we conduct brief interviews on the topic of the cost of capital and the risk premium to understand the question that CFOs believe they are answering. We conducted 12 interviews over the 2003-2005 period. ${ }^{4}$ We gain a number of insights from the interviews. There is remarkable consistency in the CFOs' views.

First, the CFOs closely track both their company's stock and the market. They are often called upon internally (e.g., Board of Directors) or externally (analyst conference calls) to explain their company's stock price. As a result, they need to try to separate out the systematic and idiosyncratic variation in their company's stock returns. To do this, they attempt to understand the forces that might cause systematic variation in the market.

Second, the CFOs believe that the "risk premium" is a longer-term measure of expected excess returns and best covered by our question on the expected excess return over the next ten years rather than the one-year question. Three-fourths of the interviewees use a form of the Capital Asset Pricing Model (which is consistent with the evidence in Graham and Harvey, 2001). They use a measure of the risk premium in their implementation of the CAPM. Often their 10-year risk premium is supplemented so that that company's hurdle rate exceeds their expected excess return on

\footnotetext{
${ }^{4}$ Three of these interviews exclusively focused on the risk premium question. Eight interviews were non-exclusive and based on surplus time available in the interviews in Brav et al. (2005) and Graham, Harvey and Rajgopal (2005). The remaining interview was conducted in 2005.
} 
the S\&P 500. Also, while not specified in the question, CFOs interpret the 10-year expected market return as the return to a buy-and-hold strategy. As a result, our survey measures the geometric rather than arithmetic average return.

Figure 1

10-year forecasted S\&P 500 returns over and above the 10-year Treasury bond yield

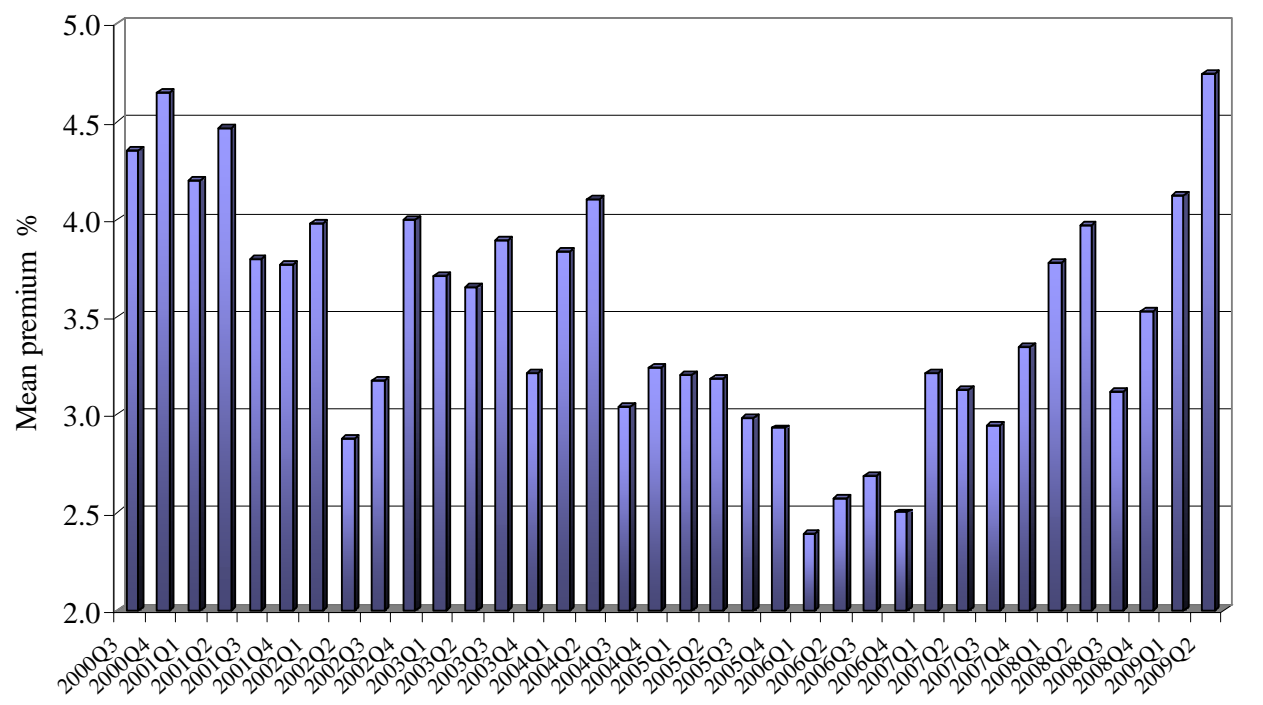

\subsection{Explaining variation in the risk premium}

While we document the level and a limited time-series of the long-run risk premium, statistical inference is complicated by the fact that the forecasting horizons are overlapping. First, we have no way of measuring the accuracy of the risk premiums as forecasts of equity returns. Second, any inference based on regression analysis is confounded by the fact that from one quarter to the next, there are 38 common quarters being forecasted. This naturally induces a moving-average process.

We do, however, try to characterize the time-variation in the risk premium without formal statistical tests. Figure 2 examines the relation between the mean premium and previous one-year returns on the S\&P 500. 
Figure 2

The equity risk premium and past 1-year returns on the S\&P 500 index

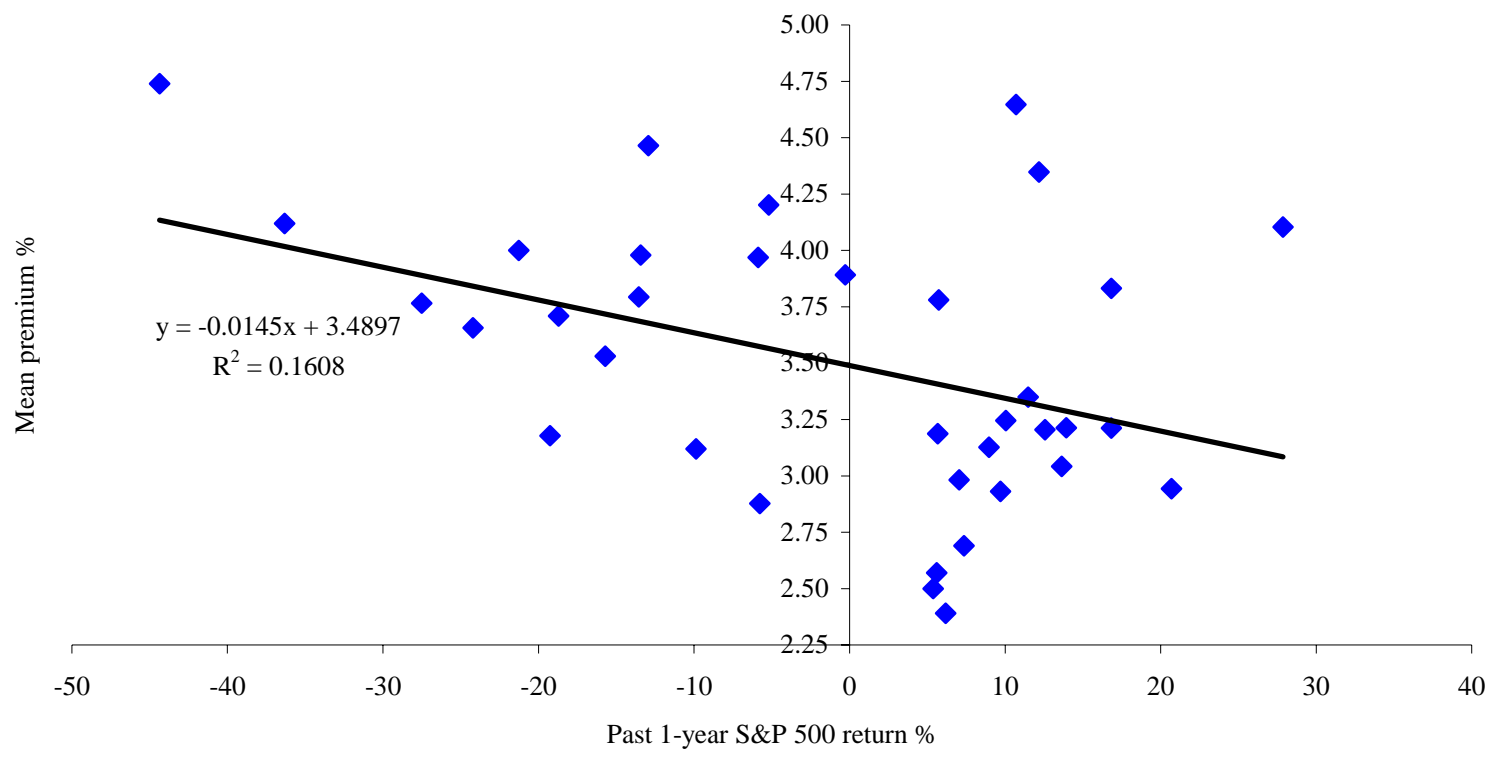

The evidence suggests that there is a weak negative correlation between past returns and the level of the long-run risk premium. This makes economic sense. When prices are low (after negative returns), expected return increase.

An alternative to using past-returns is to examine a measure of valuation. Figure 3 examines a scatter of the mean premium versus the price-to-earnings ratio of the S\&P 500 . 
Figure 3

The equity risk premium and the S\&P 500 price-to-earnings ratio

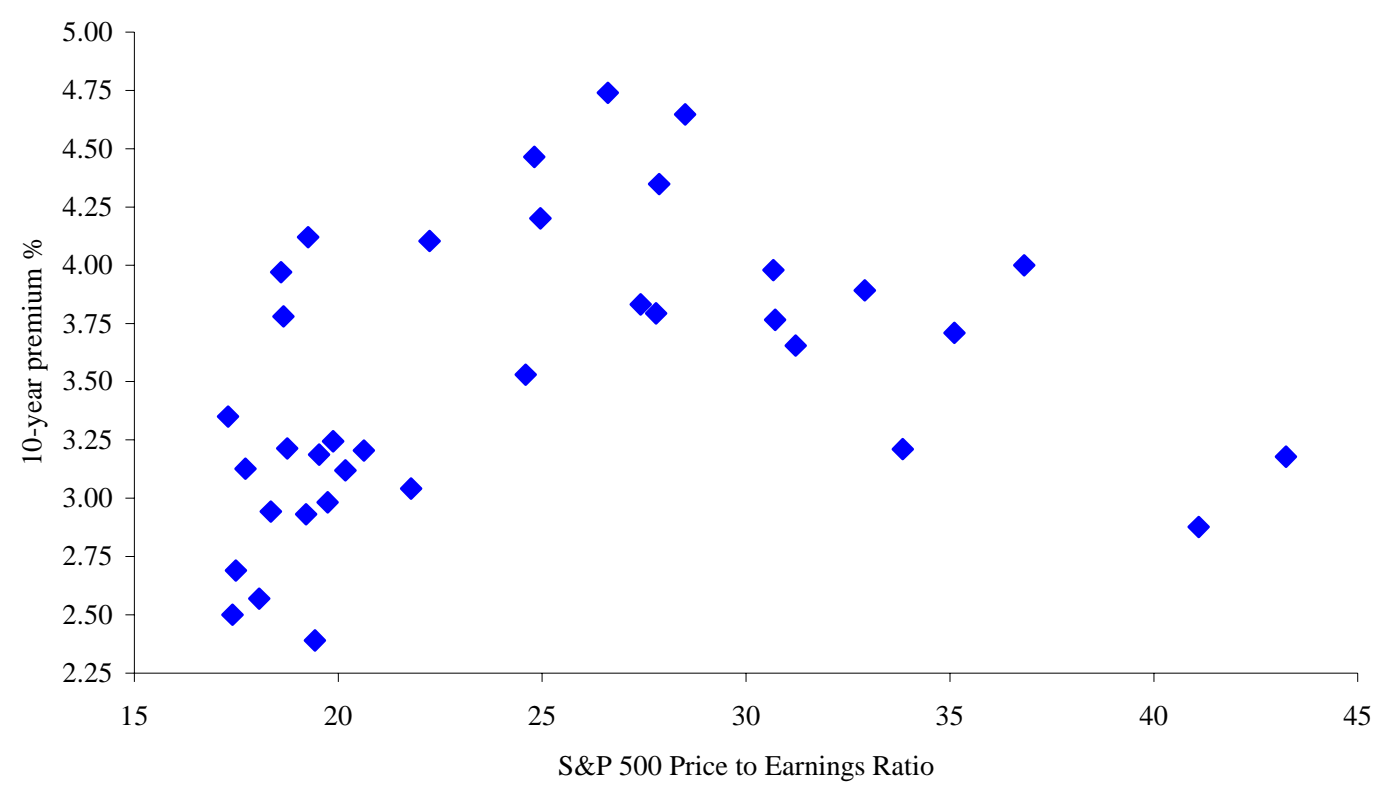

Looking at the data in Figure 3, it appears that the inference is complicated by a non-linear relation. At very high levels of valuation, the expected return (the risk premium) was low.

We also examine the real yield on Treasury Inflation Indexed Notes. The risk premium is like an expected real return on the equity market. It seems reasonable that there could be a correlation between expected real rates of return stocks and bonds. Figure 4 examines the 10-year on the run yield on the Treasury Inflation Indexed Notes. 
Figure 4

The equity risk premium and the real yield on Treasury Inflation Indexed Notes

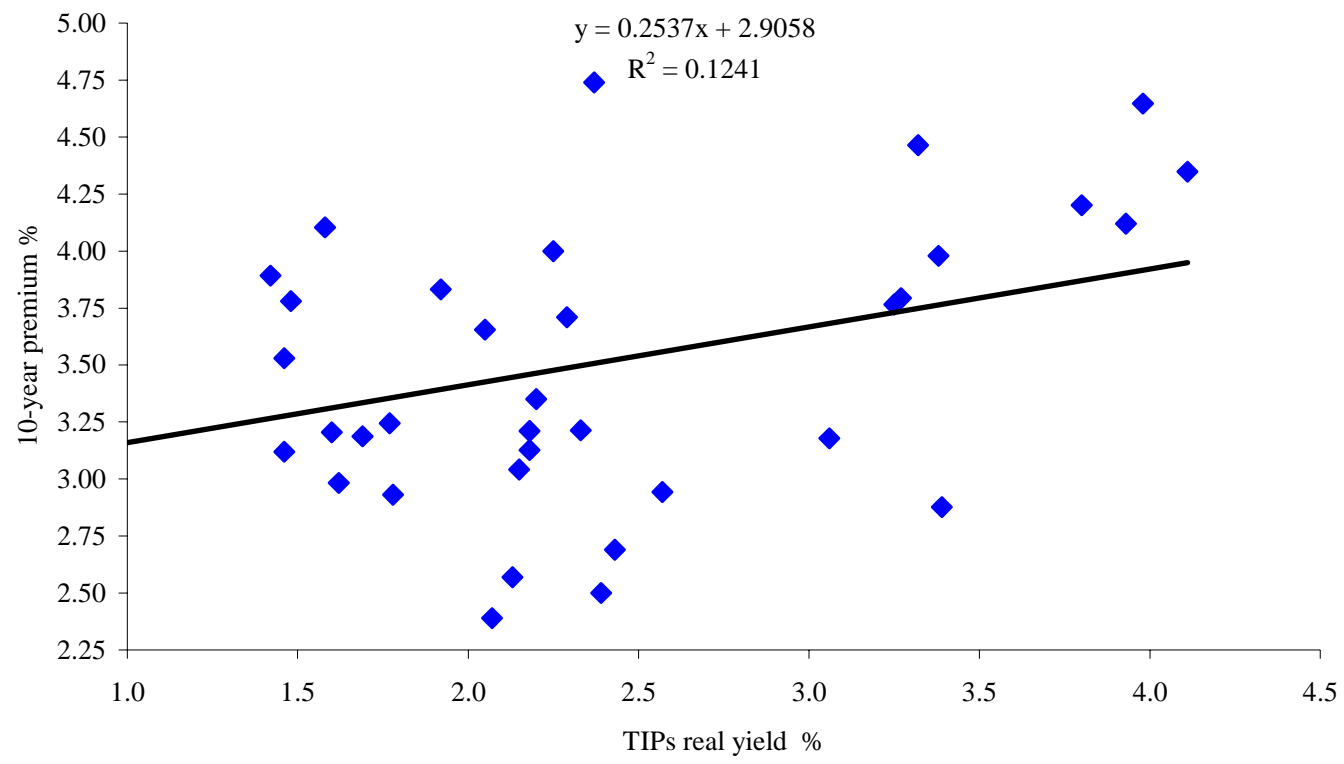

In this case, there is a weak positive correlation. Lower TIPS yields are associated with lower equity risk premiums. However, the analysis is only suggestive that the long-run equity premium and real interest rates move together.

Finally, we consider two measures of risk and and the risk premium. Figure 5 shows that over our sample there is evidence of a strong positive correlation between market volatility and the longterm risk premium. We use a five-day moving average of the implied volatility on the S\&P index option (VIX) as our volatility proxy. The correlation between the risk premium and volatility is 0.68. If the closing day of the survey is used, the correlation is roughly the same. Asset pricing theory suggests that there is a positive relation between risk and expected return. While our volatility proxy doesn't match the horizon of the risk premium, the evidence, nevertheless, is suggestive of a positive relation. 
Figure 5

The equity risk premium and the implied volatility on the S\&P 100 index option (VIX)

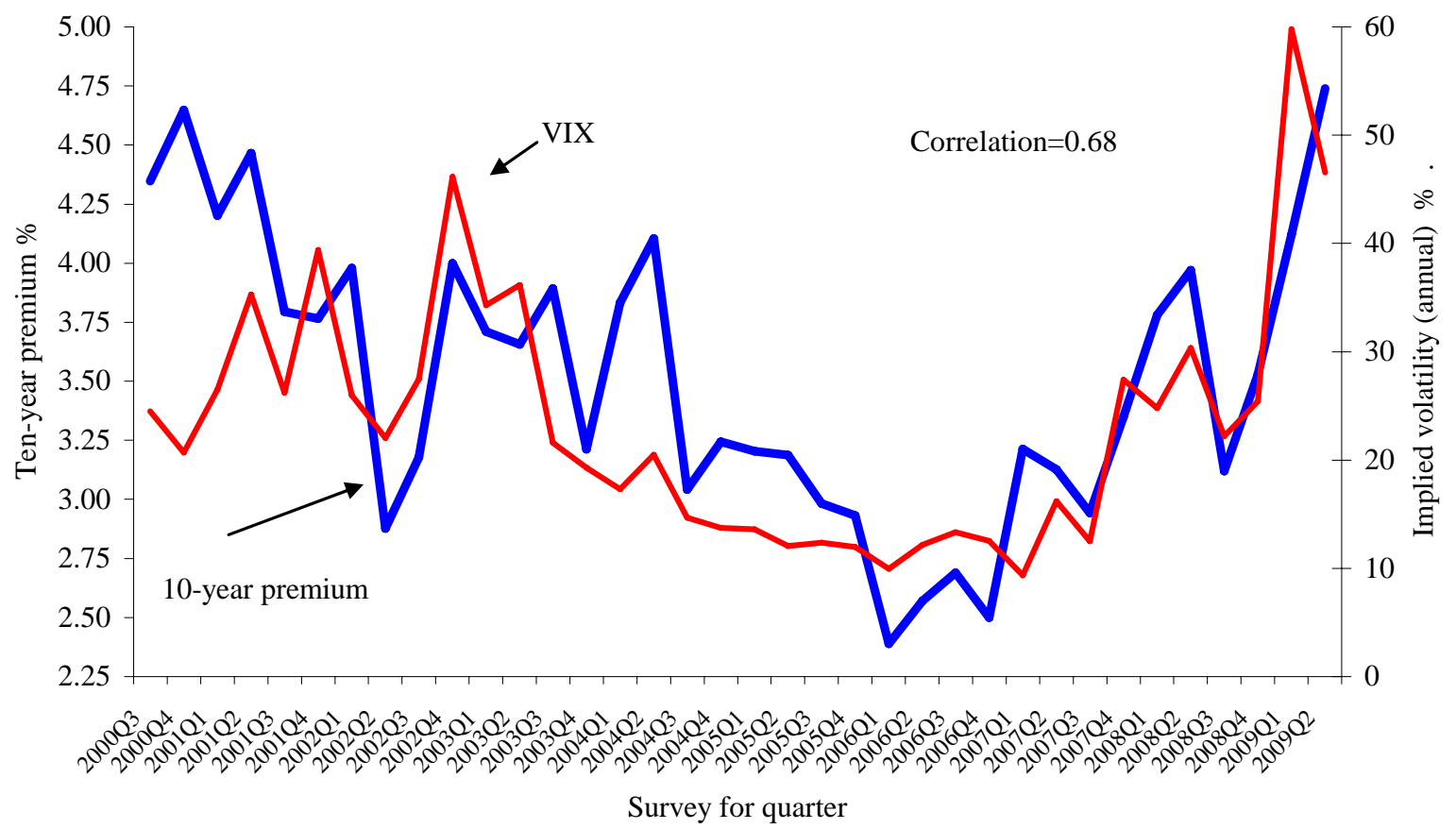

We also consider an alternative risk measure, the credit spread. We look at the correlation between Moody's Baa rated bond yields less the 10-year Treasury bond yield and the risk premium. Figure 6 shows a highly significant relation between the time-series with a correlation of 0.61 . 
Figure 6

The equity risk premium and credit spreads

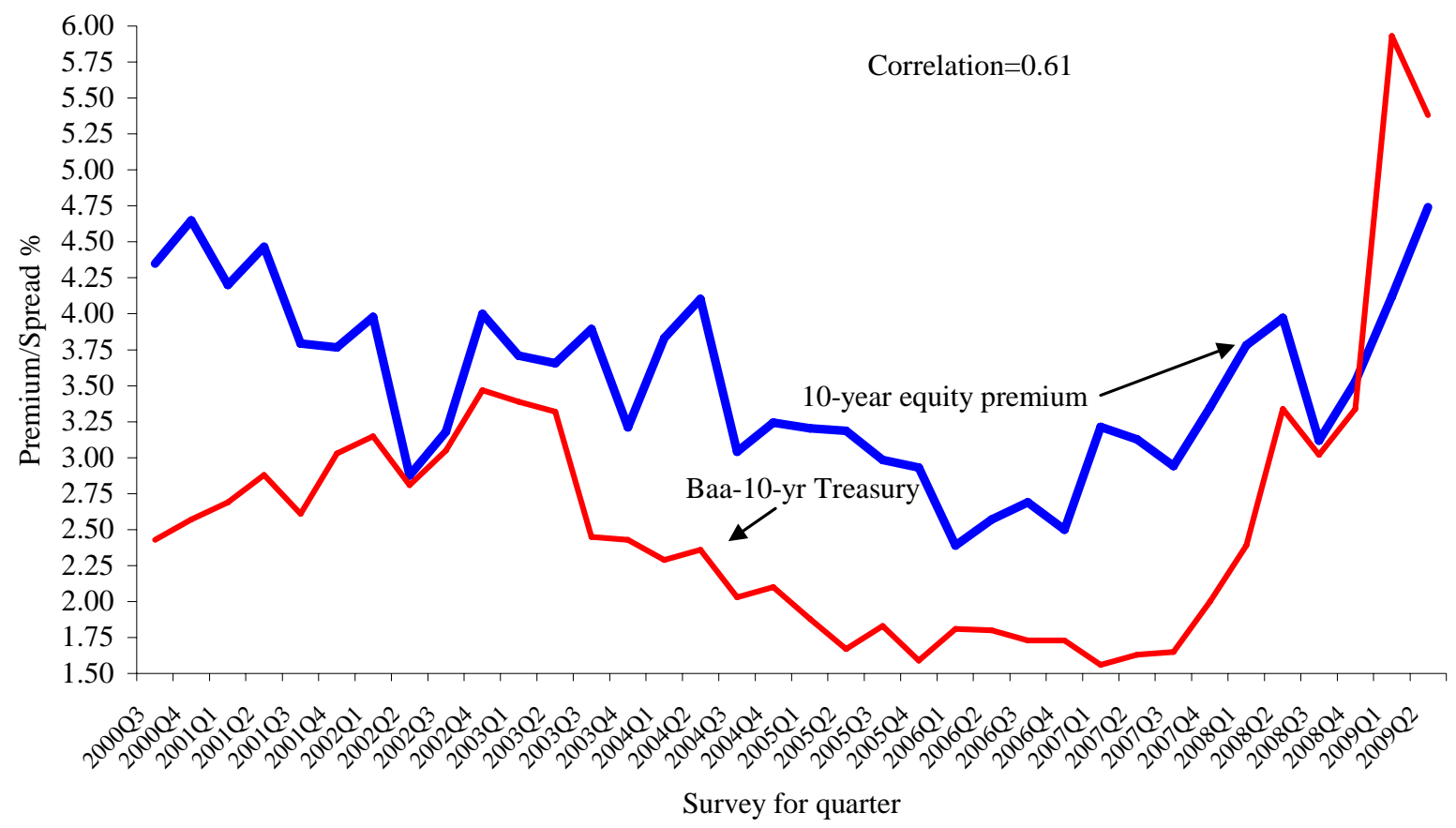

\subsection{Other survey questions}

The March 2009 survey contains a number of other questions. http://www.cfosurvey.org presents the full results of these questions. The site also presents results conditional on demographic firm characteristics. For example, one can examine the CFOs views of the risk premium conditional on the industry in which the $\mathrm{CFO}$ works.

\subsection{Risk premium data and corporate policies}

New research by Ben-David, Graham and Harvey (2009) uses the one-year risk premium forecasts as a measure of optimism and the $80 \%$ confidence intervals as a direct measure of overconfidence. By linking email addresses that respondents provide to archival corporate data, Ben-David et al. find that the tightness of the confidence intervals is correlated with key corporate policies. Overconfident managers invest more, rely on long-term debt and pay fewer dividends. They also find that the managers repurchase more shares during a decline in share prices but issue fewer shares following a 
price appreciation. The tightness of the risk premium confidence interval is also linked to executive compensation. The remuneration in firms with more overconfident CFOs is skewed towards performance-based compensation.

Campello, Graham and Harvey (2009a,b) use the survey during the financial crisis and the higher risk premiums to examine the implications of financial constraints on the real activities of the firm. They provide new evidence on the negative impact of financial constraints on firms' investment plans.

\subsection{CFO Survey compared to other surveys}

Table 2 compares the predictive ability of the Duke-CFO survey with other popular surveys. The table reports the correlations between the current quarter Duke-CFO survey of either optimism about the economy or optimism about the firm's prospects with the subsequent quarter's realization for five surveys: UBS-Gallup, CEO Survey, Conference Board Consumer Confidence, University of Michigan Consumer Confidence and ISM Purchasing Manager's Index. Both of the Duke-CFO optimism measures significantly predict all five of these popular barometers of economic confidence. Related analysis shows that our CFO survey anticipates economic activity sooner (usually one quarter sooner) than do the other surveys.

Table 2

The ability of the Duke CFO survey to predict other surveys

\begin{tabular}{lcc} 
Survey & $\begin{array}{c}\text { Predictive correlations } \\
\text { Optimism about } \\
\text { economy }\end{array}$ & $\begin{array}{c}\text { Optimism about } \\
\text { firm's prospects }\end{array}$ \\
\hline UBS-Gallup & 0.289 & 0.380 \\
CEO Survey & 0.814 & 0.824 \\
Conference Board Consumer Confidence & 0.513 & 0.767 \\
University of Michigan Consumer Confidence & 0.341 & 0.253 \\
ISM Purchasing Managers Index & 0.694 & 0.497 \\
\hline
\end{tabular}




\section{Conclusions}

We provide a direct measure of ten-year market returns based on a multi-year survey of Chief Financial Officers. Importantly, we have a 'measure' of expectations. We do not claim it is the true market expectation. Nevertheless, the CFO measure has not been studied before.

While there is relatively little time-variation in the risk premium, a number of patterns emerge. We offer evidence that the risk premium is higher during recessions and non-recessions. Given the current global economic crisis, the risk premium has hit a record high for our nine-years of surveys. We also present evidence on disagreement. With higher disagreement, people often have less confidence in their forecasts. We find that disagreement is also higher in recessionary times and the current level of disagreement is at a record level.

While we have 11,288 survey responses over nine years, much of our analysis uses summary statistics for each survey. As such, with only 36 unique quarters of predictions and a variable of interest that has a 10 -year horizon, it is impossible to evaluate the accuracy of the market excess return forecasts. There is some weak correlation between past returns, real interest rates and the of risk premium. In contrast, there is significant evidence on the relation between two common measures of economic risk and the risk premium. We find that both the implied volatility on the S\&P index as well as a commonly used measure of credit spreads are highly correlated with the risk premium.

\section{References}

Asness, C. S., 2000, Stocks vs. bonds: Explaining the equity risk premium, Financial Analysts Journal, May/June.

Ben-David, I., J. R. Graham, and C. R. Harvey, 2008, Managerial Overconfidence and Corporate Policies. Unpublished working paper, Duke University and the Ohio State University.

Brav, A., J. R. Graham, C. R. Harvey, and R. Michaely, 2005, Payout policy in the $21^{\text {st }}$ century, Journal of Financial Economics 77:3, 483-529.

Campello, M., J.R. Graham and C. R. Harvey, 2009a. The real effects of financial constraints: Evidence from a financial crisis, Unpublished working paper, University of Illinois and Duke University. Available at SSRN: http://ssrn.com/abstract $=1318355$

Campello, M., J.R. Graham and C. R. Harvey, 2009b. The long-term cost of the financial crisis, Unpublished working paper, University of Illinois and Duke University. Available at SSRN: http://ssrn.com/abstract= 1357806

Claus, J. and J. Thomas, 2001, Equity premia as low as three percent: Evidence from analysts' earnings forecasts for domestic and international stock markets, Journal of Finance 56, 1629-1666. 
Davidson, L. B., and D. O. Cooper, 1976, A simple way of developing a probability distribution of present value, Journal of Petroleum Technology, September, 1069-1078.

Fama, E. F. and French, K. R., 2002, The equity premium, Journal of Finance 57, 637-659.

Fernandez, P., 2004 Market Risk Premium: Required, Historical and Expected, Unpublished working paper, University of Navarra. Available at SSRN: http://ssrn.com/abstract $=601761$

Fernandez, P., 2006 Market Risk Premium in 100 Textbooks, Unpublished working paper, University of Navarra. Available at SSRN: http://ssrn.com/abstract=1148373

Fernandez, P., 2009 Market Risk Premium Used in 2008 by Professors: A Survey with 1,400 Answers, Unpublished working paper, University of Navarra. Available at SSRN: http://ssrn.com/abstract=1344209

Gebhardt, W. R., C. M. C. Lee, and B. Swaminathan, 2001, Toward an implied cost of capital, Journal of Accounting Research 39, 135-176.

Goyal, A. and I. Welch, 2003, Predicting the risk premium, Management Science 49, 639-654.

Graham, J. R. and C. R. Harvey, 2001, Theory and practice of corporate finance: Evidence from the field, Journal of Financial Economics 60, 187-243.

Graham, J. R. and C. R. Harvey, 2003, Expectations of equity risk premia, volatility and asymmetry from a corporate finance perspective, Working paper, Available at SSRN: http://ssrn.com/abstract=292623

Graham, J. R., and C. R. Harvey, 2009, The CFO Global Business Outlook: 1996-2009. http://www.cfosurvey.org.

Graham, J. R., C. R. Harvey, and S. Rajgopal, 2005, The Economic Implications of Corporate Financial Reporting, Journal of Accounting and Economics 40, 3-70. Working paper available at SSRN: http://ssrn.com/abstract=491627

Harris, R. S. and F. C. Marston, 2001, The market risk premium: Expectational estimates using analysts' forecasts, Journal of Applied Finance 11, 6-16.

Harvey, C. R., 2001, The specification of conditional expectations, Journal of Empirical Finance 8, 573-638.

Jagannathan, R., E. R. McGrattan and A. Scherbina, 2001, The declining U.S. equity premium, Quarterly Review, Federal Reserve Bank of Mineapolis.

Keefer, D. L. and S. E. Bodily, 1983, Three-point approximations for continuous random variables, Management Science 29, 5 595-609.

Pástor, L. And R. Stambaugh, 2001, The equity premium and structural breaks, Journal of Finance 56, 1207-1239.

Poterba, J. M. and Summers, L. H., 1995, A CEO survey of U.S. companies' time horizons and hurdle rates, Sloan Management Review, Fall, 43-53.

Siegel, J.J., 1999, The shrinking equity premium, Journal of Portfolio Management, 10-17.

Welch, I., 2000, Views of financial economists on the equity premium and other issues, Journal of Business 73 (October): 501-37.

Welch, I., 2001, The equity premium consensus forecast revisited, Unpublished working paper, Cowles Foundation for Research in Economics, Yale University, New Haven, CT. Available at SSRN: http://papers.ssrn.com/sol3/ papers.cfm?abstract_id=285169.

Welch, I., 2009, Views of economists about the equity premium and policy, Unpublished working paper, Brown University. Available at http://welch.econ.brown.edu/academics/equpdate-results2009.html 
Appendix A

\section{Excerpt from the Survey Instrument}




\section{Duke University/CFO Global Business Outlook Survey First Quarter 2009}

No individual firms are identified and only aggregate data are made public. Please respond by February 26. If you have any questions about this survey, please contact us....

17. On February 16, 2009 the annual yield on 10-yr treasury bonds was $2.9 \%$. Please complete the following:

a. Over the next 10 years, I expect the average annual S\&P 500 return will be:

Worst Case: There is a 1 -in-10 chance the actual average return will be less than:

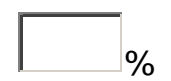

Best Guess: I expect the return to be:
Best Case: There is a 1-in-10 chance the actual average return will be greater than:

b. During the next year, I expect the S\&P 500 return will be:

Worst Case: There is a 1 -in-10 chance the actual return will be less than:
Best Guess: I expect the return to be:
Best Case: There is a 1-in-10 chance the actual return will be greater than:
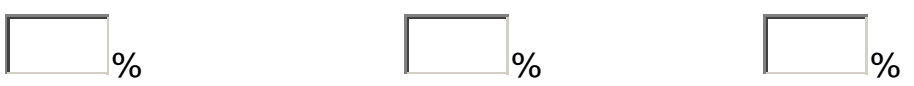

18. Please check one from each category that best describes your company:

\section{a. Industry}

\begin{tabular}{|c|c|c|c|}
\hline \multirow{5}{*}{$\begin{array}{l}\mathrm{C} \\
\mathrm{C} \\
\mathrm{C} \\
\mathrm{C} \\
\mathrm{C}\end{array}$} & Retail/Wholesale & \multirow{2}{*}{ C } & Tech [Software/Biotech] \\
\hline & Mining/Construction & & Banking/Finance/Insurance \\
\hline & Manufacturing & $\mathrm{C}$ & Service/Consulting \\
\hline & Transportation/Energy & C & Healthcare/Pharmaceutical \\
\hline & Communications/Media & C & Other: \\
\hline \multicolumn{2}{|c|}{ b. Sales Revenue } & \multicolumn{2}{|c|}{ c. Number of Employees } \\
\hline $\mathrm{C}$ & Less than $\$ 25$ million & $\mathbf{C}$ & Fewer than 100 \\
\hline $\mathbb{C}$ & $\$ 25-\$ 99$ million & C & $100-499$ \\
\hline C & $\$ 100-\$ 499$ million & $\mathbf{C}$ & $500-999$ \\
\hline C & $\$ 500-\$ 999$ million & C & $1,000-2,499$ \\
\hline C & $\$ 1-\$ 4.9$ billion & C & $2,500-4,999$ \\
\hline C & $\$ 5-\$ 9.9$ billion & C & $5,000-9,999$ \\
\hline
\end{tabular}


Graham-Harvey: The equity risk premium amid a global financial crisis

\begin{tabular}{|c|c|}
\hline $\mathbf{C}$ More than $\$ 10$ billion & C More than 10,000 \\
\hline & Submit \\
\hline & Jniversity, 2009 \\
\hline
\end{tabular}

